"We have still to inquire into the causes which led to the Siberian migration, and to ascertain the geological period during which it took place. In order to arrive at a more satisfactory conclusion on these problems, it is of some moment to study the extinct fauna of Siberia." (p. 449.)

"Since Tcherski has shown that Western Siberia is largely covered by fresh-water deposits, the assumption that the Aralo-Caspian had been in direct communication with the Arctic Ocean as recently as the Pliocene epoch can no longer be maintained; but, as we shall see presently, there is some evidence in favour of a European connection between the two seas." (p. 453.)

( $T$ o be continued in our next Number.)

\title{
COERESPONDENTOE.
}

\section{TRESPASSERS, BEWARE!}

Sir,-I am grateful to my " kalikali" colleague, Mr. F. A. Bather, for pointing out that (in common with the more learned palæontologists who have recently prepared a Synopsis and a Revision of the Cystoidea) I had overlooked the fact of a new name having been proposed for Hall's Echinocystis in the last edition of his friend Mr. S. A. Miller's Catalogue.

In regard to Discocystis, a defence of the name would involve a greater trespass into the domain of the Cystoidea than I was recently forced to make in relieving the term Echinodiscus from double duty in Echinoderm nomenclature. A review in the current number of Natural Science helps me to resist the temptation; for the reviewer, whose information is apparently of the best, deplores the brief treatment of the Cystoidea in the new Guide to the Fossil Invertebrata in the British Museum, although "our National Museum possesses not only a fine collection of those rarities, but an officer well qualified to deal with them."

J. W. GRegory.

\section{TRINUCLEOS SETICORNIS.}

Srr,-It is satisfactory and instructive to find in last month's Geological Magazine Mr. Marr so clearly indicating his early mistake about the range of Trinucleus seticornis, for he mentions in his criticism of my remarks that in 1883 he had stated that this species was nowhere found in the Upper Bala, while in 1885 he was led to call some Upper Bala beds in South Wales the $T$. seticornis beds, on account of its abundance in them. After this presumably conscious acknowledgment of an error, I am, therefore, surprised to find Mr. Marr much troubled in mind because I naturally considered that his statement of 1885 considerably qualified, or even negatived, his earlier one of 1883 . Perhaps Mr. Marr wishes to make another correction in his opinions published in 1885 .

With regard to the identification of this protean species of trilobite I exceedingly regret that infallibility cannot be claimed as a prerogative by eminent geologists, or even by "very competent palæontologists," at any time of their life, and that consequently Mr. Marr 